\title{
The Biopolitics of Asylum Law in Texas: The Case of Mexicans Fleeing Drug Violence in Juárez ${ }^{1}$
}

\author{
Ariadna Estévez*
}

\begin{abstract}
Using Michel Foucault's concept of biopower, this article examines the role of asylum law in the control of Mexican migration to the U.S., arguing that U.S. authorities are using asylum law as a new means of regulating Mexican immigration. The article relies on theoretical input and empirical data to prove that there are extra-legal and technical legal issues allowing for the biopolitical use of asylum law, usually linked to sovereign power.
\end{abstract}

Key words: asylum law, immigration, drug violence, biopolitics, Mexico-U.S. relations, sociolegal studies.

\section{RESUMEN}

A partir del concepto de biopoder de Michael Foucault, este artículo examina el papel de las leyes de asilo para controlar la migración mexicana hacia Estados Unidos. Se argumenta que las autoridades estadunidenses están usando las leyes de asilo como un nuevo medio para regular la inmigración mexicana. Se basa en herramientas teóricas y datos empíricos para demostrar que existen tecnicismos legales y otros aspectos no circunscritos al ámbito legal, generalmente ligados al poder soberano que permiten el uso biopolítico de la ley de asilo.

Palabras clave: ley de asilo, inmigración, violencia a causa del narcotráfico, biopolítica, relaciones México-Estados Unidos, estudios sociolegales.

\footnotetext{
${ }^{1}$ The fieldwork for this article was possible thanks to the Research Fund 2012 of the Mexican Association of International Studies (AMEI). The author is grateful for AMEI's support.

* Researcher at the Centro de Investigaciones sobre América del Norte, unAM, aestevez@unam.mx
} 
Thousands of people have fled the war against drug trafficking in Mexico (20062012); over 700000 persons have been displaced, 230000 from the Juárez Valley in Chihuahua alone (Benavides and Patargo, 2012). Of those who left the Juárez Valley, 150000 are now in the United States (Displacement Monitoring Centre and Norwegian Refugee Council, 2011), and hundreds of asylum applicants have been unsuccessful because U.S. courts systematically reject their petitions. Certain empirical studies suggest that the denial of asylum is linked to economic and political interests, since the U.S. government either does not wish to question the authority of its trading partner or does not want to open the door for the migration of nationals from countries that already represent a migration threat, as is the case of Mexico (Rosenblum and Salehyan, 2004; Ramji-Nogales, Schoelholtz, and Schrag, 2007; Camp and Holmes, 2009).

However, the focus of this article is not the empirical evidence that makes the case for identifying the political and economic interests leading to the denial of asylum to Mexican citizens. Instead, it will focus on the role of asylum law in the biopolitics of U.S. migration control and how it helps sustain those interests. It will argue that systematic rejection is related to the tactical use of asylum law in the migration dispositif (apparatus) of U.S. biopolitics, which treats Mexicans as a threat. It uses both theoretical input and empirical data (interviews with asylum seekers' attorneys and asylum advocates) to advance its central argument. The case study used for analysis is international forced displacement in the Ciudad Juárez, Chihuahua-El Paso, Texas border region. ${ }^{2}$

The article will therefore first characterize and contextualize the broader migration panorama, the phenomenon of Mexican asylum seekers in the U.S. in general and El Paso, Texas, in particular. It will then discuss how biopolitics is a suitable framework for analyzing the managerial use of asylum law for regulating immigration into the U.S. Finally, it will discuss the legal and extra-legal components of asylum law that are used as a biopolitical tactic in the Fifth Circuit migration courts to regulate Mexican political migration.

\footnotetext{
${ }^{2} \mathrm{El}$ Paso has been taken as case study since most asylum applications here are related to the problems dealt with here. Although in the U.S. the details and nature of cases are confidential, some activists and academics have revealed that, while many of the California cases involve indigenous people fleeing traditional political harassment in Oaxaca and Chihuahua and gender and sexual orientation-based persecution in conservative parts of Mexico, most cases registered in Texas, and particularly in El Paso, are related to violence resulting from the war on drugs in Ciudad Juárez.
} 


\section{Characterizing and Contextualizing Mexican Asylum Claims As Part of the Broader Phenomenon of Migration}

The U.S. government and Pew Hispanic Center have agreed that the flow of undocumented Mexican immigrants has slowed in recent years: in January 2008, there were an estimated 11.9 million undocumented immigrants in the country, but by January 2009, that number had dropped by almost one million, possibly due to the fact that immigrants had decided to return to their countries of origin due to the economic recession. By 2012, the migration rate from Mexico had dropped to zero percent according to the Pew Hispanic Center, which stated, "The standstill appears to be the result of many factors, including the weakened U.S. job and housing construction markets, heightened border enforcement, a rise in deportations, the growing dangers associated with illegal border crossings, the long-term decline in Mexico's birth rates, and broader economic conditions in Mexico" (Passel, Cohn, and Gonzalez-Barrera, 2012).

While undocumented crossings by Mexicans have decreased, in this period a new migration trend has appeared: forced displacement and asylum, especially in the context of twin border cities such as Ciudad Juárez-El Paso. Drug-related violence in the Juárez Valley, among other cities considered strategic for the illegal drugs business, such as Nuevo Laredo, Morelia, Veracruz, and Monterrey, has led to shootouts, people being caught in the crossfire, decapitations, and the use of car bombs against government authorities and rival gangs. In addition, kidnappings, extortion, forced disappearances, and the execution of civilians have become daily occurrences. The human toll of this violence has been devastating, with the loss of over 100000 lives (Ramírez de Alba, Solís, and De Buen, 2012) and the forced disappearance of 26000 people (Amnistía Internacional, 2013). As for displacement, between 2010 and 2011 some 700000 people had to leave their homes as a consequence of generalized violence throughout the country and two percent of the Mexican population (over 1.6 million people) has been forcibly displaced by criminal violence (Benavides and Patargo, 2012). In the Juárez Valley alone, 230000 people have been forced to abandon their homes with the majority seeking refuge in the U.S., especially Texas (Benavides and Patargo, 2012; Displacement Monitoring Centre, and Norwegian Refugee Council, 2011).

In 2007, a year after the war on drugs was declared, 9545 Mexicans requested asylum, an increase of 41 percent compared to the previous year. Between 2006 and 2010, 44019 Mexicans applied, 13700 of them in the United States and 30142 in Canada. Until 2007, most Mexican asylum seekers chose Canada (74 percent) and to a lesser extent the United States (24 percent). However, by 2010, this trend had changed. The number of Mexican asylum claims in the United States increased in 2008 to 2 487; in 2009 it remained almost the same, but in 2010 the number almost doubled (4 225) (United 
Nations High Commissioner for Refugees 2007, 2008, 2009, 2010). In contrast, in Canada the number of Mexican asylum claims reached 9413 in 2008, although by 2010 this number had dropped to 1 198, evidently due to the new visa requirement imposed on Mexican citizens (United Nations High Commissioner for Refugees, 2007, 2008, 2009, 2010). While in 2001, only 50 Mexicans requested asylum in the United States, by 2007 the number had jumped to 1830 . In 2008, it rose to 2487 , and in 2009 , to 2422 . In 2010, the figure shot up to 4225 (United Nations High Commissioner for Refugees, 2007, 2008, 2009, 2010); by 2011, the claims had soared to 8 906, and in 2012, to 11477 (United Nations High Commissioner for Refugees, 2011, 2012). By 2010, Mexico was responsible for one of the highest numbers of asylum requests in the United States, second only to China, and followed by Haiti, Guatemala, and El Salvador (USDOJ, 2011).

According to the Transactional Records Access Clearinghouse (TRAC), in 2012 over one-third of the court backlog of asylum applications were those of Mexicans (113 829 out of a total of 305 556), followed only by China, Honduras, El Salvador, and Guatemala. Except for the courts in Guam, in 2012 every U.S. American state processed applications from Mexicans; 60 percent of the cases were recorded in just four states: California, Texas, Illinois, and Arizona (2012a). Acceptance rates, on the other hand, are practically non-existent: in 2010, only 143 of 2320 cases of affirmative asylum requests were granted (6.2 percent). ${ }^{3}$ The number of successful affirmative cases decreased overall between 2008 and 2010 with 176 in 2008; 191 in 2009; and 143 in 2010. In 2010, asylum was granted in just 49 of the 3231 cases (1.5 percent). With respect to defensive asylum, the number of successful applications also dropped between 2008 and 2010 with 72 in 2008; 62 in 2009; and 49 in 2010. A total of 85 percent of all asylum claims lodged between 2008 and 2010 were denied (Dzubow, 2012).

In El Paso, Texas, where hundreds of the cases linked to the war on drug trafficking are to be found, Judges William L. Abbott and Thomas C. Roepke are responsible for some of the highest denial rates in the country and have become even tougher since Mexicans rose to among the top of the asylum application lists (TRAC, 2012b, 2012c). Abbott had a 65.7 percent denial rate in 2010, when nationals from Burma made up 19.7 percent of his caseload, ${ }^{4}$ but his denial rate rose to 74.6 percent in 2011 when Burma nationals were replaced by Mexicans, who represented 14 percent of his caseload. For his part, Abbott rose in the national denial rankings from position 113 to 77 (TRAC, 2012C). ${ }^{5}$ In his 2010 report, Roepke denied asylum in 96.7

\footnotetext{
${ }^{3}$ The differences between affirmative and defensive asylum and how they constitute a managerial aspect of asylum law and policy are dealt with later in this article.

${ }^{4}$ Nationals from Burma were followed by nationals from El Salvador (10.7 percent), China (9 percent), Mexico (8.2 percent), and Ethiopia (6 percent) (TRAC, 2012c).

${ }^{5}$ Other nationalities following Mexicans are El Salvador (13.5 percent), Burma (9.8 percent), China (6.2 percent), and Somalia (6.2 percent) (TRAC, 2012c).
} 
percent of cases; Mexicans represented 12.4 percent of his caseload. ${ }^{6}$ In his most recent report (TRAC, 2012b), the number of applications from Mexicans rose to 19 percent, ${ }^{7}$ and his denial rate remained at 96.7 percent, although he did move up in the national rankings from fourth to third place on a list of 256 judges (TRAC, 2012b).

So, who are these Mexican asylum seekers whose cases are systematically rejected? They are mostly local government authorities such as mayors and city councilpersons from all political parties who flee after colleagues and/or relatives have been killed in Ciudad Juárez or small towns in the Juárez Valley, which covers the municipalities of Praxedis Guerrero and Guadalupe Distrito Bravo. They also include police officers who have refused to participate in drug-related corruption; journalists the Mexican government is either unable or unwilling to protect; human rights and women's rights activists persecuted by both criminals and state authorities; average citizens who have witnessed atrocities perpetrated by the army or drug gangs; women threatened by former partners who are drug traffickers; and small business owners from the Juárez Valley who openly refuse to pay extortion or quotas.

These people are anything but wealthy. Even those who do own property and capital flee suddenly, empty-handed, with nothing but the clothes on their backs and a couple of blankets if they are lucky. Neighbors or friends later notify them that their property or businesses have been vandalized or looted by armed men after their departure. At the end of the day, rich and poor alike arrive in El Paso with nothing more precious than their threatened lives. In order to apply for asylum some of these people manage to pay for a lawyer -not that there are many lawyers willing to take their cases. However, those who do find proper legal aid are among the pro bono cases of attorney Carlos Spector, one of the few lawyers willing to defend what his colleagues and local legal NGOs believe to be lost causes. Many of these are the clients of local NGOs dealing with migration issues, such as Las Americas Immigrant Advocacy Center or the Diocesan Migrant and Refugee Services, which run group workshops on how to fill out the I-589 form (the application for asylum and withholding of removal). They claim they cannot handle the work load -at least one family arrives every week- and that most cases will not succeed in court.

People without relatives in El Paso or Las Cruces who have managed to avoid detention -they hold visas and apply for affirmative asylum-, or were released immediately on humanitarian parole, spend their first couple of months in shelters where food is scarce and not always good quality since it is often charity, essentially

\footnotetext{
${ }^{6}$ They are followed by Guatemala (10.7 percent), Honduras (10.7 percent), El Salvador (9.1 percent), and Jamaica (6.6 percent) (TRAC, 2012b).

7 This number is followed by Honduras (10.5 percent), El Salvador (9.8 percent), Guatemala (9.8 percent), and Colombia (5.2 percent) (TRAC, 2012b).
} 
leftovers provided by local businesses. In some cases, large families live in tiny flats in some of poorest areas of El Paso, Texas, or Las Cruces, New Mexico.

The systematic denial of asylum to Mexicans is related to what Anna Jessica Cabot, managing attorney for Las Americas Immigrant Advocacy Center, claims to be "this feeling that when you start letting in Mexican citizens that experienced drug violence, then you're opening the doors to hundreds of thousands of Mexican citizens because drug violence is so pervasive in Mexico" (2012). Officials in Washington share this fear and support the use of biopolitical tactics, according to Carlos Spector, attorney-at-law and legal representative of dozens of Mexicans seeking asylum in El Paso. He claims that cartels are acting as state agents and that victims as well as asylum authorities are aware of it. However, granting asylum to Mexicans would be tantamount to opening "Pandora's Box," he claims (2012).

To sum up briefly, data indicates that, while undocumented migration has slowed, a new migration trend related to drug violence has begun: application for asylum. While thousands of people have fled to other towns in Mexico, many others seek asylum in the U.S. These are not wealthy Mexicans, but Mexicans who are regularly disciplined through security controls and are now biopolitically regulated through asylum law. That is, Mexicans are now regulated through the managerial use of asylum law, as will be discussed below.

\section{EXPLAINING Biopolitics ANd ITS LINKS To Asylum Law}

While it was not Foucault's intention to write a theory of power, he did venture an analytical philosophy of power that establishes how it works and its capabilities for subjection (Castro, 2004: 204). This analytical work focuses on differentiation systems, instrumental modalities, and how power is institutionalized. For Foucault, power is the conduct of conduct, since it is not exercised directly on people but by inducing, facilitating, hindering, limiting, and preventing their actions. Power relations become relations of domination when blocked using techniques that permit complete domination of the actions of others. Foucault identified the use of three types of power in European history: sovereign power, disciplinary power, and biopower, and all three historical types of power overlapped rather than replaced each other (Foucault, 2000, 2004; Foucault, Senellart, and Davidson, 2007). Whereas sovereign power is exercised through legal apparatuses and disciplinary methods, biopower is enforced through a very different set of objectives, objects, rationality, apparatuses, strategies, and struggles or resistances. 
Biopower modifies the sovereign's right to let live and make die, essentially inverting the relationship: instead of letting live and making die, the state now exercises the right to make live and let die. ${ }^{8}$ Through the use of these techniques the state does not replace disciplinary power, but incorporates it and takes it to another level or sphere of action where different devices are used. It addresses human life not in its individual dimension but as a whole (the population as a species), which is fragmented in terms of race and ethnicity. While disciplinary power is focused on individual bodies (anatomo-politics), biopower focuses on processes specific to life itself, such as birth, death, reproduction, mobility, and disease. In biopower, the technologies used are also different: medicine, statistics, birth control policy, or anything intended for use as a means of population control (Castro, 2004; Foucault, 2000, 2006a; Foucault, Senellart, and Davidson, 2007). Those who "threaten" the survival of the majority are left to die by their omission as objects of policy and other technologies (for instance, the banning of primary health services for undocumented migrants).

The rationality of biopower is governmentality -in modern Western societies this is liberal governmentality-, which includes the set of institutions, analyses, calculations, and tactics focused on population as the main objective, while political economy gives it shape, and security apparatuses are its main instruments (Castro, 2004: 130131). Governmentality is not exclusive to the state since these techniques control the possible actions of other subjects, or self-directed actions for the domination of pleasures and desires. In order to differentiate political governmentality from other types of governmentality, Foucault referred to the first as "governmentalization of the state." This process has turned the justice state -the sovereign state ruled by law-into the managerial state (Castro, 2004: 130-131), which administrates life through its specific techniques. This is why the regulation of migration, the policy intended to define who is allowed to enter and remain in a territory and who is not, is a fundamental subject of biopolitical analysis.

In fact, biopolitics has become a widespread analytical tool for the examination of migration policy as an instrument of contemporary neoliberal governmentality (Bastos, 2008; Bigo, 2002; Bolaños, 2009; Ceyhan and Tsoukala, 2002; Fitzgerald, 2010; Kalm, 2005; Kelly, 2004; Kunz, 2008; Vaccotti, n/ d; Yuing, 2011). Many of these works are based on Roberto Esposito's re-interpretation of Foucault's biopolitics (2005), in which he makes an analogy between the politics of life and the human body's immune system, saying that the latter fights exogenous threats the same way biopower

\footnotetext{
${ }^{8}$ Evidently a discussion of biopolitics and its complex relationship with the historical development of capitalism and liberalism could be more extensive and sophisticated, but such a discussion would move beyond the scope of this article. The interested reader should refer to more extensive and specific sources such as Foucault (2000, 2004, 2006a, 2006b); Foucault, Senellart, and Davidson (2007); Castro (2004); and Lemke (2010: 190-207).
} 
fights "pathogen" forms of life threatening the majority. He then distinguishes between politics over life and politics of life. What we face today is a politics over life, which works as an immune system defending the body -the population-through negative means that eventually turn against the system itself, excluding other types of life from the community. Migration policy is therefore a form of immunization against the threat of pathogenic groups (migrants and asylum seekers) (Esposito 2005).

Biopolitics has also been effective in examining the management of precarious lives -to paraphrase J. Butler-in migration and asylum policies in Europe, Australia, and the U.S. (Darling, 2009; Edkins and Pin-Fat, 2005; Muller, 2004; Owens, 2009; Tyler, 2010; Zylinska, 2004). The work of Giorgio Agamben has been fundamental in the latter line of research. Agamben returns to the reflections of Foucault on biopolitics and compares it to biological life using the Greek concept of Zoe, that is, the simple life separate from, and opposed to, Bios, or political life. Agamben identifies the origin in the inclusion of Zoe in political power in the figure of homo sacer. The homo sacer is a political-legal figure from the ancient world that refers to a person who has been judged and accused of a crime; while they cannot be sacrificed, anyone who kills them will not be accused of homicide. These people are left completely unprotected by the law and their inclusion is solely a result of their exclusion. The bare life of homo sacer is subject to the political only by exception. For Agamben, homo sacer as the person who can be killed but not sacrificed is the first figure to establish the biopolitical power of the sovereign since it subjectivizes the bare life not through its inclusion in the legal order except through its exclusion (Agamben, 1998). For Agamben, refugees serve as the best representation of the contemporary homo sacer, since they are only included in the political and legal domains by means of their exclusion and can be killed without it being considered homicide. The refugee embodies the concept of the bare life, purely biological human existence with no political value, and for this reason the protection of this life is removed from the political sphere and becomes a strictly humanitarian concern. Detention camps for refugees are therefore the new concentration camps and serve to express the totalitarian sophistication of contemporary biopolitics.

I agree with the idea that the migration apparatus serves U.S. American biopolitics and is essentially a "defense" against the "threat" of Mexican migration. I also believe that asylum seekers embody the idea of the homo sacer since they are people who exist only because they are outside the law (Agamben, 1998); and that migrants and asylum seekers are a pathogen against which immunization (immigration and asylum policy) is enforced. However, the focus of this article is different, since it concerns more specifically an examination of the use of asylum law in the biopolitics of migration in the U.S. The article therefore analyzes the biopolitical use of law in practice. 
In Foucauldian terms, law pertains to complementary sovereign and disciplinary powers: while the first results in legal codes, the second implements these codes institutionally (Foucault, 2006; Foucault, Senellart, and Davidson, 2007). Nevertheless, law is strategically used in biopolitics due to the development of biopower, and norms become more important than the judicial system itself. This does not mean that law or its institutions tend to disappear, but that the law increasingly serves as a norm intended to impose conformism and homogenize, and that judicial institutions are more integrated into a continuum of apparatuses with regulatory functions (Castro, 2004: 219). It is a regulatory mechanism in the politics of life and death, even if law is used to carry axiological content in the sovereign state, such as the law protecting refugees.

The article will therefore argue that even though asylum law should not form part of biopower, it does. Through its legal texts, asylum discourse in the United States serves as a tactic for the regulation of migration, which in turn has economic and political objectives: to defend U.S. American territory from the threat of Mexican migration and maintain the credibility of security cooperation between Mexico and the U.S.

\section{The Biopolitical Role of Asylum Law}

According to Foucault, the ideal vehicles of power are discourses, elements, or tactical blocks used in power relations to construct subjectivities (Castro, 2004: 219), and they operate through apparatuses (dispositifs, or the non-discursive instruments linked to discourses) maintained through a variety of strategies. Several legal categories exist in asylum discourse that construct the persecuted subject, and these are codified in various legal texts. Asylum is defined in terms of the United Nations Convention Relating to the Status of Refugees (1951) and its Protocol (1967); withholding of removal implements the obligation of non-refoulment established in the Convention of Refugees; and prevention of deportation due to a well-founded fear of being the subject of torture, is enforced as complementary means of protection under the Convention against Torture and Other Cruel, Inhuman, or Degrading Treatment or Punishment.

A dispositif, or apparatus, is a set of social relationships built around a discourse: institutions, laws, policies, disciplines, scientific and philosophical statements, concepts, and moral propositions. As part of the migration apparatus, asylum discourse is produced and distributed under the control of large political and economic technologies such as courts, immigration offices, and law firms (Castro, 2004). Through these, asylum discourse in the migration apparatus excludes a subject of asylum $a$ 
priori if he/she has participated in the persecution of others in connection with one or more of the five protected grounds; stayed in the U.S. for over a year at the time of the application; or resettled successfully in another country.

Once a person is eligible for asylum, his/her claim will be successful if he/she manage to prove, in terms of the politics of truth in asylum discourse established by the Immigration and Nationality Act (INA 101[a] [42]), that he/ she has a well-founded fear of persecution due to the government's unwillingness or inability to protect the victim from his/her persecutors; and that this persecution is motivated by the victim's race, nationality, religion, political opinion, or membership of a particular social group. These two concepts (the government's unwillingness or inability to protect and the motivation) determine the scope of the construction of the subject of asylum law.

As part of the U.S. migration apparatus, asylum discourse is enforced managerially, although its reproduction, signification, and power techniques resemble those of sovereign power, such as courts. In the words of Gibney, "The United States essentially has had no refugee policy as such -only an immigration policy disguised as a refugee policy" (2000: 53). Two features of asylum law and its enforcement are central to its biopolitical use: the extralegal aspects surrounding its enforcement, and the technical legal issues derived from interpretation.

\section{Extralegal Issues}

As stated above, in biopolitics the law serves justice, but it is used to homogenize populations. In this case, openly managerial features exist in the enforcement of asylum law that show how instruments intended for the administration of international justice, such as the Refugee Covenant included in the INA, are used to regulate immigration to the U.S. The biopolitical tactics facilitating migration control are as follows: splitting the system into affirmative and defensive procedures and the quasilegal character of migration administration of justice that leaves ample room for subjective and arbitrary decisions. Firstly, the division of asylum into affirmative and defensive procedures allows for differential treatment of claimants according to their socioeconomic status and gender, which supposedly determines their criminal proclivity. Affirmative applicants are those who enter the country with a valid visa, or those who overstay their visas and therefore hold no documents authorizing them to remain in the country. These claims are reviewed by an asylum officer from the U.S. Citizen and Immigration Services (USCIS) and if not approved, they are referred to an immigration judge of the Executive Office for Immigration Review (EOIR), a branch of the U.S. Department of Justice that fails to operate as a proper 
court, as will be seen later. Only at this time is the applicant transferred to removal proceedings, although his/her application has not been yet rejected. The denial letter explains, "This is not a denial of your asylum application. You may request asylum again before the immigration judge and your request will be considered (without additional re-filing) when you appear before an immigration judge at the date and time listed on the attached charging document."

Many Mexicans who pass through El Paso courts are in defensive asylum, although they began affirmative procedures. Immigration officers who deny asylum to Mexicans in affirmative proceedings do not give in-depth legal arguments when informing them of their decisions. They only state that the applicant has failed to prove past or future persecution, but do not explain why. In defensive claims a migration officer places the applicant in removal proceedings, and the case goes directly to the EOIR. Typically, claimants who opt directly for defensive asylum are those who do not have a visa and state their intention to seek asylum to an immigration officer at a port of entry. In these situations, asylum seekers are sent to detention centers where they are held until an immigration court makes a decision, which could take up to five years. While awaiting the judge's decision, ${ }^{9}$ applicants can request a "credible fear" interview, that is, an interview in which they have to provide evidence that their fear of persecution is well founded. The judge then either grants or denies asylum and proceeds to removal (Rottman, Fariss, and Poe, 2009).

The success of the claimant's credible fear interview depends entirely on the judge's perception. This prerogative is granted by the 1996 Real ID Act, which, according to Cabot, gives judges the "negative credibility decision, with which he can decide that asylum seekers are not credible based on any inconsistencies in the story, even inconsistencies that have no bearing on the actual claim of asylum (the color of a house, the time of day that something happened, etc.). This kind of subjective assumption is sufficient for a judge to justify dismissing asylum seekers' testimony." Cabot also claims that inconsistencies such as these are frequent in the case of Mexican asylum seekers, given that “they haven't seen attorneys, and also many people flee the border, actually run to the border; we have people who have been shot and [they] take them to the hospital when they get to the border, [they are] cleaned up, drugged up, on painkillers, and sent back to the border for their interview; they're on painkillers, hours after being shot, and say things that are mildly consistent with things they say in the future, their testimony gets discarded" (2012). She goes on to say that

\footnotetext{
${ }^{9}$ In December 2009, President Barack Obama determined that asylum seekers able to prove "credible fear" of persecution by their country's government, or by a group the government did not want to control or was unable to control, could remain in the U.S. until such time as the asylum application process was completed. The problem, however, comes when people are required to demonstrate "credible fear."
} 
this is an important determining factor in the rejection of cases because, "if you have a judge with the preconceived notion that Mexican people should not be given asylum, and with the power to decide that the asylum seeker is just not believable based on [small] things ... then it is incredibly easy for that judge just to say ... 'your testimony is not credible'" (2012).

Crystal Massey, a human rights advocate and former researcher at Carlos Spector's law firm, which deals with most Mexican cases, claims that the affirmative/ defensive divide has no other objective than to serve as a filter for the type of Mexicans who can access the asylum system; this does not mean they are granted asylum, just access to the system. Massey argues that people with visas are usually middle class, well-informed Mexicans with the means or the knowledge to obtain a border crossing document, or know that stating an interest in asylum at the border will lead to them being placed in detention. Massey also claims that young men spend more time in detention (men are associated with the drug business or gangs in the biased mind of U.S. civil servants or judges). In detention, people are mistreated (they are forced to remain in degrading and uncomfortable conditions for long periods) or harassed (they are separated from young children and told they could remain separated for a very long time) to pressure them to drop their asylum claims.

Secondly, U.S. immigration courts are administrative, managerial bodies that administrate migration, rather than disciplinary bodies in charge of controlling sovereign power. The quasi-legal or quasi-administrative character of immigration courts makes decision-making subjective and arbitrary. In the U.S., they are not constitutional like civil or criminal courts where people can claim rights. According to Cabot, immigration courts are "something that is court-like; it's actually an administrative body, and the administrative body says okay, immigration benefits are such important things to people that we should give people a place that looks like a court basically in order to make sure that their rights are more likely to be appealed in this area" (2012). Their decisions are appealed with the Board of Immigration Appeals, whose published decisions are law only for the circuit where the claim was based. Only when the asylum-seeker appeals a judge's decision to the Supreme Court does his/her case enter a constitutional field. Although these administrative bodies look like courts, law enforcement is relaxed and discretionary. In fact, says Cabot, the law "can be changed based on the judge who oversees the court. ... Each particular judge can alter the rules within their own court, and so this gives the judges much more discretionary powers than judges in other courts in the U.S., criminal courts, civil courts . . to change the rules to suit their own biases and preconceptions than they do in another arenas" (2012).

Interviewees claim that judges evaluating Mexican asylum seekers in the Fifth Circuit (Texas, Louisiana, and Mississippi), in detention or at liberty, are tougher 
than judges in other circuits. According to Iliana Holguín, executive director/attorney at law, at the Diocesan Migrant and Refugee Services, Fifth Circuit judges deny asylum in 95 percent of cases, while Ninth Circuit judges (California) grant asylum in over 50 percent of cases (2012). Not only that, Fifth Circuit judges have made asylum restrictions even tougher, as can be seen in their decisions to narrow particular social groups (see below). According to Cabot, judges in the Fifth Circuit are extremely conservative and believe that granting asylum to some Mexicans will open the door for all Mexicans fleeing violence. This argument, she claims, is easily refuted because even if judges admit "people fleeing drug violence" as a group for the purposes of asylum, these people still have to prove they are being persecuted, and that this persecution is by the state. Furthermore, since "immigration judge decisions are not law, they're not precedential published decisions, so one immigration judge that starts to give asylum to people from Mexico fleeing violence doesn't mean that by law the whole border is now open; it's still a decision-by-decision thing" (2012).

Another tactic judges use to prevent access to the system is the one-year bar. Petitioners become ineligible for asylum if they apply after having been in U.S. territory for over a year. People submit their asylum application (form I-589) together with their testimony and evidence during their first meeting with judges, at their "master hearing." Because judges handle so many cases, there is a delay in case review of over two years (some petitioners who arrived in 2012 will not have their master hearing until 2014). According to Holguín, case review is faster in the detention court, basically because detention centers are privately-run and the government has to pay for every asylum seeker detained there, so they try to speed up the process to save money. However, cases are often dismissed because no legal advice was provided and the one-year bar was ignored. Holguín claims that due to their awareness of this situation, judges are now willing to review cases more quickly. In fact, she says, they have made a commitment to review three cases in three and half hours, something that also makes it clear that "they already know in what terms they're going to make their decision" (2012).

\section{Technical Legal Issues}

In the second place, although extralegal techniques are key to defining the managerial status of asylum law, legal texts play a fundamental role in the regulation of Mexican migration. Asylum law has truth effects concerning what constitutes an act and a victim of persecution, as well as the context in which persecution occurs. It has created a politics of truth (the establishment of subjectivities, objects, and concepts that 
separate true from false) in which the definition of state attribution, responsibility, context, and victim excludes many subjectivities, objects, and concepts. The narrow interpretation of two legal categories serves as a biopolitical technique for regulating Mexican flows: 1) a well-founded fear of present or future persecution due to the state's unwillingness or inability to protect them; and 2) that they are or could be the victims of persecution because of their nationality, race, religion, political opinion, or membership in a particular social group.

Firstly, fear of persecution is defined as a fear of serious harm and the failure of the state to provide protection vis-à-vis this possibility. Persecution could be understood as "the sustained or systematic violation of human rights demonstrative of a failure of state protection" (Price, 2006). The level of harm must be severe. In order to demonstrate persecution, a person's experience must be more than simple unpleasantness, harassment, or even basic suffering. According to the un Asylum Handbook, persecution could be an action by the state or the result of the state's inability to control the criminality of non-state actors (García, 2011; Pickering, 2005). Two interpretations exist of persecution by non-state agents in the face of which the state is willing but unable to provide protection. One, the view of protection, in which the definition is extended to cover situations where the state of origin is incapable of providing the necessary protection, and two, the view of accountability, which establishes that only when persecution emanates from the state can the person be considered a refugee (Bruin, 2002).

However, the involvement of non-state actors is not the main problem facing Mexican asylum seekers, as Cabot explains: "That issue, in my opinion at least, is not the most pressing issue because in some ways in asylum law this 'unwilling or unable clause,' it doesn't even matter for asylum law whether the police are involved or not, to some extent because, whether they're involved, maybe they're unwilling to stop the violence; if they're not, maybe they're unable to stop the violence" (2012). The non-state actor issue is in fact problematic for protection provided under the Convention against Torture since protection is only for people who have been tortured or could be tortured by state officials, or with the acquiescence of the state. If a claimant cannot prove persecution on account of one of the five protected grounds, this possible avenue of protection is also banned if there is no state involvement.

According to Cabot and fellow attorney Nancy Oretskin, for Mexican claimants, the main issue is to prove the Mexican government's inability or unwillingness to protect its citizens from persecution or torture by state authorities or criminals. As Oretskin puts it, in the end, "the key always is, no matter whether political opinion or social group, the government or representative of the government is incapable or unwilling to protect you. You have to have a tie to the government. ... So the tying 
with the cartels, in the missing piece of the U.S. denying to Mexico is the refusal to recognize the cartels as the government" (2012).

In terms of asylum law, the difficulty of proving the Mexican government's complicity with drug cartels has to do with such factors as law enforcement officials being on the payroll of cartels, even though the state enforces the Mérida Initiative. In order to prove the state's inability or unwillingness to fight drug cartels, claimants' lawyers submit recommendations to the USCIS or EOIR from Mexican human rights commissions or news clippings reporting that law enforcement officials or soldiers directly participated in, or ignored, murders related to the case. However, these are not always forthcoming and testimony may be the only available proof. In response, asylum authorities use evidence of Mexican or bilateral policy on the fight against drug trafficking. In Cabot's words, "Because there is involvement of the state, but clearly the state in Mexico is not a monolithic actor; the state doesn't just do one thing or another; there are loads of different actors within the state itself, you know, the office of the president and the military could be saying conflicting things ... because there is so much conflicting action within the government, I mean obviously the government is fighting itself at some level, just saying that there is involvement doesn't prove that there is involvement in a specific person's case" (2012).

Secondly, given the characteristics of the Mexican situation, arguing motivation is never straightforward either. As Cabot claims, "When you're dealing with people who are fleeing from drug violence, there's no obvious group, no obvious ground ... you know, it's not their race, religion, nationality, so those go out the window" (2012). Therefore asylum claimants have only two category options: political opinion and membership in a particular social group. However, given the characteristics of the war on drugs, the connections to political opinions or social groups are clear only in the most traditional cases.

Political opinion refers to "any opinion on any matter in which the machinery of the State, government, and policy may be engaged" (Buchanan, 2010: 44). Even if the applicant has not expressed his/her opinions yet, the strength of his/her convictions leads to the assumption that the applicant will eventually express them and will enter into conflict with authorities (Buchanan, 2010). To address this possibility, Spector has created the political association Mexicans in Exile, designed to speak out against impunity and demand justice for the murders or disappearances of relatives of Mexican asylum seekers. Given that the asylum process could take up to five years, if people prove political involvement in Mexicans in Exile, they might be able to argue future persecution.

So far, however, people who have managed to demonstrate a well-founded fear of persecution due to their political opinions are those expressing a political opinion 
in terms of the INA and the UN Convention, that is, typical asylum seekers. In the words of Cabot, "For some people fleeing Mexico, there's political opinion; that actually works for them, but that's usually politicians, journalists, or human rights activists. So that's specifically for people who speak out and doesn't apply just to the normal person fleeing violence" (2012). For instance, in September 2010, the U.S. government granted political asylum to journalist Jorge Luis Aguirre, director of $\mathrm{La}$ Polaka.com, when he managed to flee Ciudad Juárez just a few hours after the execution-style murder of journalist Armando "Choco" Rodríguez and after having received an anonymous phone call warning him, "You're next." Aguirre offered a political rather than legal defense of his case before the U.S. Senate Subcommittee on Crime and Drugs in Washington during a hearing in March 2009.

Another, similar, case is that of Alejandro Hernández Pacheco, a journalist who was also granted political asylum. In August 2011, the Court ruled in his favor after he demonstrated credible fear of persecution by federal authorities for denouncing their failure to protect him from a drug cartel. In 2010, he had been kidnapped after reporting that Gómez Palacio, Durango, jail authorities released prisoners at night so that they could carry out cartel-ordered assassinations. Hours after his release, federal police informed him he would be meeting then-President Felipe Calderón. However, he was instead taken to a press conference where his face and identity were revealed to the national media. Another case is that of human rights activist Cipriana Jurado, who managed to demonstrate she was persecuted by army officials due to her activism in favor of a family seeking justice for two of its members (two women) who were reported missing in the Juárez Valley in 2009. She was granted political asylum in June 2011.

Mexican law enforcement officials also have a good chance of making a case for political asylum: "Police officers can argue that by reason of their political opinion to not associate or cooperate with the drug trafficking business, they have been persecuted or have a fear of persecution. This is a plausible argument given that the concept of political opinion is defined broadly and that some drug trafficking cartels are effectively a political force in that they continuously seek to infiltrate government institutions, particularly law enforcement departments" (Buchanan, 2010).

Nevertheless, people who speak out against the drug cartels and are consequently persecuted by sicarios (hit men) face the greatest difficulties, such as the Morín Brothers. ${ }^{10}$ Since 1989, the Morín brothers have owned a public transport company in Ciudad Juárez, Chihuahua, and shortly after its founding they joined a PRI-affiliated union confederation. In addition to the three brothers, another five family members

\footnotetext{
${ }^{10}$ The author had access to the legal files of all the cases described here, but the claimants' identities will not be disclosed to protect the safety of the families in question and that of the author.
} 
went into the business. In 1997, they operated 10 buses and by 2005 they had received another 10 bus concessions. From then on, they began to hire drivers, since prior to that they had done the driving themselves.

In June 2008, a drug cartel began to extort them, making death threats and warning they would burn their homes and buses if they failed to pay the cartel Mex\$5 000 a week. The brothers tried to organize union members to avoid making these payments and to stage a public protest. However, they were warned that if they continued to organize others against the cartel's interests, their buses would be incinerated. One of the brothers suggested the group organize a general strike and refuse to provide bus services, thereby exerting pressure on the police. The union members present agreed to take action but ultimately were afraid, and so no group action was taken at the meeting. A phone call was later received saying that a bus had been set on fire and that if they continued to advocate strikes and resist extortion the cartel would kill a family member. Shortly thereafter, the son of one of the brothers was murdered execution-style in a Juárez bar, and in March 2011 the Morín family fled to El Paso. Calling publically on others to organize a united front against extortion qualifies as political opinion, according to attorney Carlos Spector, who also believes that the Morín brothers were not persecuted on an individual basis but as a family with strong political opinions. However, the Morín brothers have been denied affirmative asylum and find themselves in defensive proceedings.

There are other cases that appear more like typical cases of political opinion but that have nevertheless been rejected, probably due to the general context of drugrelated violence. This is the case of a local perredista (a member of the Party of the Democratic Revolution, or PRD) who applied for asylum based on a well-founded fear of persecution due to his political opinions and the Mexican government's unwillingness or inability to protect him. He claimed,

I believe I would be harmed because of my political opinion. I believe this because of what I have seen: soldiers who block roads and yank people from their cars and beat them, abusing their rights. They have killed people. . . If a person asks for help or seeks justice, that person turns up dead. I believe that either the Mexican government or military has intended to send me a message that based on my political position as a councilman that opposes the actions of the Calderon government I am at great risk of being killed, disappeared, tortured, or kidnapped.

He applied for asylum as part of affirmative proceedings, but his application was denied in May 2012 because he allegedly failed to prove past or future persecution. He was immediately placed in removal proceedings because his visa had expired in 
January 2012 and he had remained in the country. He entered through Fabens, Texas, in March 2011, and appeared before an immigration judge on July 17, 2012. This local perredista was a friend of the Reyes Salazar family, ${ }^{11}$ who he had met during protests against the Sierra Blanca nuclear waste dump. Both he and the Reyes Salazar family headed the protest. When in the summer of 1998 a 19-year-old mother and maquila worker disappeared, the Antinuclear Coalition started working on the case, and her body was found a week later. Their demands for justice led to the detention of a man who had also killed another young woman. Josefina Reyes Salazar then set up the Committee for Human Rights in the Juárez Valley which the local perredista joined. In 2006-2007, he joined Andrés Manuel López Obrador in the fight against the privatization of Mexico's state-owned oil company, Pemex, and in 2008 he joined Josefina Reyes and Cipriana Jurado in their fight against military abuse. During the Calderón administration, at least 11 elected officials, PRD candidates, or their family members were assassinated in Chihuahua. The local perredista was elected city councilman in 2007 in Guadalupe Distrito Bravo; however, he only served three years of his four-year term because three of his colleagues were murdered during this period. While he believes it was the federal police who threatened him and his colleagues, he also suspected the Juárez mafias were responsible for the murder of his colleagues and relatives.

On the other hand, regarding membership in a particular social group, in most cases the reasons cited are not explicitly those of the INA and the UN Convention, that is, the persecution by sicarios and corrupt law enforcement officials of entire families who either refuse to pay extortion or speak out about extortion; or the killing of murder victims' relatives seeking justice for the deceased. More specifically, for the Fifth Cir-

\footnotetext{
${ }^{11}$ A paradigmatic case of Mexican asylum seekers is that of the Reyes Salazar family, who have been persecuted both for their political opinions and their family line. Six members of the family have been killed since the Joint Chihuahua Operation was launched: Julio César Reyes Salazar (Josefina's son, who was murdered in November 2009); Josefina Reyes Salazar (murdered in March 2010); Rubén Reyes Salazar (brother, murdered in August 2010); María Magdalena Reyes Salazar (sister, murdered in July 2011); Elías Reyes Salazar; and Luisa Ornelas de Reyes (sister-in-law, murdered in July 2011). Josefina's remaining son, Miguel Ángel, was arrested on organized crime charges in 2008 for alleged links with a drug cartel, but was immediately released. The home of Sara, Josefina's mother, was burned down in her absence. The surviving members of the Reyes Salazar family (mother Sara; brother Saúl, with his wife and 3-, 6- and 12-year-old sons; sisters Olga, Claudia and Marisela; and nephews Jorge Luis, Ismael, and Ángel) traveled to Mexico City in 2011 seeking protection from the federal government after they received death threats. The Attorney General's Office placed them in a shelter, but they decided to leave a month later since long-term solutions were not offered. The surviving members of the family seized the opportunity to flee to El Paso, Texas, where all except Ismael applied for asylum. Ismael refused to leave Mexico and remained hidden in Ciudad Juárez, where he has a wife and a child, as well as a former partner and another son. Sara did go to El Paso but refused to file for asylum because she did not want to be in a position that would prevent her return to Mexico to visit Ismael. However, in June 2012, Ismael received a phone call from his former wife to tell him that armed men had visited her and asked about him. He immediately left for El Paso, and finally Ismael and his grandmother Sara applied for asylum. In only four years, an entire family was run out of Chihuahua.
} 
cuit, a particular social group must have the following three key characteristics: social visibility, immutability, and particularity.

The Fifth Circuit defines visibility as society's perception of a group as a visible social group. Oretskin describes this in the following way: "In the Fifth Circuit of Texas where we are, membership of a social group is hard [to demonstrate] because you have to prove it is immutable, and you have to show visibility. Visibility is participating in protests and pictures. Immutability is a member of the family who has been in the media, and that the media covered this around the world because of the injustice. How's that immutable? How can you change that you're part of that family? So the social group is hard. Really hard" (2012).

Immutability refers to people who share an innate or unalterable characteristics such as their past, defined by something as basic as their identity that they should not be required to abandon (Buchanan, 2010; Pickering, 2005). For example, police officers and law enforcement officers in general could be granted asylum on account of their membership in particular group because they have a "shared past experience" and share "a common immutable characteristic," which is having been law enforcement officials, a feature that cannot be changed (Buchanan, 2010; García, 2011).

According to Cabot, this is specifically linked to characteristics unrelated to persecution itself: "The other thing about a social group is, in order to kind of prevent circular logic, ... your social group cannot be defined by the persecution that it suffers; for example, women who suffer domestic violence cannot be a social group because domestic violence is the persecution itself. So, Mexican citizens targeted by cartels cannot be a social group because this is being defined by the persecution. That prevents us from using what might be the most obvious social group, a fairly visible thing. That's one problem" (2012). Therefore, people who refuse to pay quotas to drug cartels, criminal informants, Mexicans returning from the U.S., and business persons (wealthy merchants or families) are groups that are too broad to qualify as a "particular group." In addition, there is no voluntary relationship or innate characteristic to bind its members (García, 2011).

A possibility for establishing a particular social group for Mexicans is the family, since family meets the criteria of a particular social group: "Family membership is a characteristic that a person either cannot change (if he or she is related by blood) or should not be required to change (if he or she is related by marriage)" (The United States Court of Appeals for the Fifth Circuit, 2011: 15). Nevertheless, in the Fifth Circuit, it is not enough to belong to a family of a persecuted person; persecution on account of family as a social group seeks "to terminate a line of dynastic succession" (The United States Court of Appeals for the Fifth Circuit, 2011: 7). However, this is much tougher in the Fifth Circuit. 
Many people have had their cases turned down in affirmative proceedings when trying to prove family as a particular social group, such as the Vázquez family. In August 2011, members of the Vázquez family were having their traditional Sunday lunch and family gathering at their house in Guadalupe Distrito Bravo when eight heavily armed men descended from a black truck and burst into the garden of the house where most of the family members were assembled. The unknown men forced them to hand over their mobile phones and beat everyone present, women included. The men were looking for a three-year old boy, the son of a niece of Marisela Reyes Salazar. ${ }^{12}$ The little boy was considered a Reyes Salazar and therefore had to be eliminated. However, none of the three had arrived for the family reunion that day; since they were not present, the men got angry and took another member of the family in retaliation. This woman was kidnapped in front of her teenage daughters while her partner lay unconscious on the floor after suffering a severe beating. Before leaving, the armed men threatened to kill the entire Vázquez family if they failed to leave town that same evening. The family appealed for help from the army since they were able to identify some of the men and provided a description of the truck used to take the woman away. However, the soldiers refused to help, saying they were unable to take any action. The soldiers finally agreed to escort 14 members of the Vázquez family to the Dr. Porfirio Parra International Bridge, which connects Guadalupe with the Texan town of Tornillo, in order for them to apply for asylum. The only mistake the Vázquez Family made was being related to the Reyes Salazar family, which has been persecuted on account of both their political opinions and their family line.

This last section of the article serves to show how asylum law serves the biopolitical purposes of the U.S. government through the decisions of Fifth Circuit judges who refuse to expand the limits of asylum law and consistently use these categories to prevent Mexicans from being granted asylum.

\section{Conclusion}

The data indicate that while undocumented migration has decreased, a new migration trend has been established: application for asylum. While thousands of people have fled their homes and relocated within Mexico, those not protected by the Mexican state seek asylum in the United States. Consequently, asylum law, which usually corresponds to sovereign power, begins to play a biopolitical role.

\footnotetext{
12 See note 11 for details concerning the Reyes Salazar family.
} 
In particular, certain extra-legal and technical legal issues allow this to happen. First, the extra-legal issues are related to the affirmative / defensive divide in the asylum procedure, which serves as a filter through which only middle-class Mexicans can avoid detention. In addition, the "court-like" nature of the system permits judges' subjectivity to be used. Second, the well-founded fear of persecution, the government's unwillingness or inability to protect victims from their persecutors, and persecution for reasons of political opinion or for membership in a particular social group are all used as biopolitical tactics. Judges choose not to expand the legal concept of asylum and prefer to narrow their interpretations as a means of denying this option to people fleeing violence. Both the extra-legal and technical issues evident in asylum enforcement indicate that evidence exists suggesting that the U.S. government is using asylum law biopolitically to keep Mexicans out of its territory.

\section{BibliogRAPHY}

Agamben, G.

2001 Medios sin fin, Valencia, Spain, Pre-textos.

1998 Homo sacer. El poder soberano y la nuda vida, Valencia, Spain, Pre-textos.

\section{AMNISTÍA INTERNACIONAL}

2013 Enfrentarse a una pesadilla: la desaparición de personas en México, London, Amnesty International, 16.

BAstos, C.

2008 "Migrants, Settlers and Colonists: The Biopolitics of Displaced Bodies," International Migration, vol. 46, no. 5, pp. 27-54.

BenAVIDEs, L., and S. PATARgo

2012 "México ante la crisis humanitaria de los desplazados internos," Foreign Affairs Latinoamérica, vol. 12, no. 4.

Bigo, D.

2002 "Security and Immigration: Toward a Critique of the Governmentality of Unease," Alternatives: Global, Local, Political, vol. 27, no. 1, pp. 63-92. 
BOLAÑOS, B.

2009 "Migración, derecho consular y justicia global," Isonomía: Revista de teoría y filosofía del derecho, no. 30, April, pp. 7-30.

BRUIN, R. H. M.

2002 "Working Party on Non-State Agents of Persecution: 2002 Report," in Stemming the Tide or Keeping the Balance, the Role of the Judiciary, record of the International Association of Refugee Law Judges (IARLJ) 2002 Conference at Wellington, New Zealand, p. 451.

\section{BUCHANAN, $\mathrm{H}$.}

2010 "Fleeing the Drug War Next Door: Drug-related Violence as a Basis for Refugee Protection for Mexican Asylum-Seekers," Merkourios. Utrecht Journal of International and European Law, vol. 27, no. 72, pp. 28-60.

CABot, AnNa Jessica

2012 Oral history interview by the author with the managing attorney at Las Americas Immigrant Advocacy Center, El Paso, Texas, June 25.

CAmp Keith, L. and J. S. Holmes

2009 "A Rare Examination of Typically Unobservable Factors in US Asylum Decisions," Journal of Refugee Studies, no. 22, pp. 224-241.

CASTRO, E.

2004 El vocabulario de Michel Foucault. Un recorrido alfabético por sus temas, conceptos y autores, Buenos Aires, Universidad Nacional de Quilmes.

CeyHan, A., and A. Tsoukala

2002 "The Securitization of Migration in Western Societies: Ambivalent Discourses and Policies," Alternatives: Global, Local, Political, vol. 27, no. 1, pp. 21-39.

Citizenship And Immigration CanAda

2010 "Balanced Refugee Reform. Government of Canada," August 18, http:/ / www.cic.gc.ca/english / refugees/reform.asp, accessed August 18, 2010.

DARLING, J.

2009 "Becoming Bare Life: Asylum, Hospitality, and the Politics of Encampment," Environment and Planning D: Society and Space, no. 27, pp. 649-665. 
Displacement Monitoring Centre and Norwegian Refugee Council

2011 México, Oslo, http:/ / www.internal-displacement.org/publications/global -overview-2010-americas-mexico.pdf, accessed February 5, 2014.

DzuBow, J.

2012 "Confusion Over Mexican Asylum Seeker Statistics," www.asylumist.com, http: / / www.asylumist.com/2012/03/08 / confusion-over-mexican-asylumseeker-statistics/, accessed February 5, 2014.

EDKINS, J., and V. PIN-FAT

2005 "Through the Wire: Relations of Power and Relations of Violence," Millenium: Journal of International Studies, vol. 34, no. 1, pp. 1-24.

Esposito, R.

2005 Immunitas: protección y negación de la vida, Buenos Aires, Amorrortu.

EstéveZ, A.

2012 Human Rights, Migration and Social Conflict: Towards a Decolonized Global Justice, New York, Palgrave Macmillan.

FitzGerald, S. A.

2010 "Biopolitics and the Regulation of Vulnerability: The Case of the Female Trafficked Migrant," International Journal of Law in Context, vol. 6, no. 3, pp. 277-294.

FoucAult, $M$.

2006a Defender la sociedad, Mexico City, Fondo de Cultura Económica.

2006b Seguridad, territorio, población, Mexico City, Fondo de Cultura Económica.

2004 The Birth of Biopolitics, New York, Picador-Palgrave Macmillan.

2000 Power, New York, The New Press.

Foucault, M., M. Senellart, and A. I. Davidson

2007 Security, Territory, Population: Lectures at the College de France, 1977-78, Basingstoke, Palgrave Macmillan.

GARCíA, S.

2011 "Asylum for Former Mexican Police Officers Persecuted by the Narcos," Boston College Third World Law Journal, vol. 31, no. 2, pp. 245-267. 
GiBNEY, M.

2000 "In Search of a US Refugee Policy," in D. P. Forsythe, ed., The United States and Human Rights. Looking Inward and Outward, Lincoln, Nebraska, University of Nebraska Press, pp. 52-72.

\section{Hernández Pacheco, Alejandro}

2012 Oral history interview by the author with the journalist and political refugee in El Paso, Texas, June 27.

Holguín, ILIANA

2012 Oral history interview by the author with the lawyer and executive director of the Diocesan Migrant and Refugee Services, Inc., El Paso, Texas, June 24.

KALM, S.

2005 “Towards Global Migration Management? A Biopolitical Approach,” paper presented at ISA Conference, March 1-5, Honolulu, All Academic Research, http: / / citation.allacademic.com / / meta / p_mla_apa_research_citation / 0 / 6/9/4/6/pages69460/p69460-1.php, accessed June 1, 2011.

KeITH, L. C., and J. S. Holmes

2009 "A Rare Examination of Typically Unobservable Factors in US Asylum Decisions," Journal of Refugee Studies, vol. 22, no. 2, pp. 224-241.

KeLLY, M.

2004 "Racism, Nationalism and Biopolitics: Foucault's Society Must Be Defended, 2003," Contretemps, no. 4, September, pp. 58-70.

KunZ, R.

2008 "Mobilising Diasporas: A Governmentality Analysis of the Case of Mexico," Lucerne, University of Lucerne, Faculty of Humanities and Social Sciences. Institute of Political Science, http: / / www.unilu.ch/files/Diaspora-governing _wp03. pdf, accessed June 1, 2011.

LEMKE, T.

2010 "'The Birth of Bio-politics': Michel Foucault's Lecture at the Collège de France on Neo-liberal Governmentality," Economy and Society, vol. 30, no. 2, pp. 190-207. 
Massey, Crystal F.

2012 Oral history interview by the author with the researcher/human rights advocate, El Paso, Texas, June 23.

Muller, B.

2004 "Globalization, Security, Paradox: Towards a Refugee Biopolitics," Canada's Periodical on Refugees, vol. 22, no. 1, p. 57.

\section{ORETSKIN, NANCY}

2012 Oral history interview by the author with the attorney, El Paso, Texas, June 24 .

OWENS, P.

2009 "Reclaiming 'Bare Life'?: Against Agamben on Refugees," International Relations, vol. 23, no. 4, pp. 567-582.

\section{Passel, J., D. V. Cohn, and A. GonZalez-Barrera}

2008 "Net Migration from Mexico Falls to Zero-and Perhaps Less," Pew Hispanic Center, http: / / www.pewhispanic.org/2012/04/23/net-migration-frommexico-falls-to-zero-and-perhaps-less /, accessed in October 2008.

PICKERING, S.

2005 "Crimes of the State: The Persecution and Protection of Refugees," Critical Criminology, vol.13, pp. 141-163.

PRICE, M. E.

2006 "Persecution Complex: Justifying Asylum Law's Preference for Persecuted People," Harvard International Law Journal, vol. 47, no. 2, pp. 413-466.

Ramírez de Alba, L., L. Solís, and N. De Buen

2012 Indicadores de víctimas visibles e invisibles de homicidio, Mexico City, México Evalúa Centro de Análisis de Políticas Públicas.

Ramj-Nogales, J., A. I. Schoenholtz, and P. G. Schrag

2007 "Refugee Roulette: Disparities in Asylum Adjudication," Stanford Law Review, vol. 60, no. 2, pp. 295-411. 
ROSENBLUM, M.R., and I. SALEHYAN

2004 "Norms and Interests in US Asylum Enforcement," Journal of Peace Research, vol. 41, no. 6, pp. 677-697.

Rottman, A., C. J. Fariss, and S. C. Poe

2009 "The Path to Asylum in the US and the Determinants for Who Gets In and Why," International Migration Review, vol. 43, no. 1, pp. 3-34.

\section{SPECTOR, CARLOS}

2012 Oral history interview by the author with the political activist and attorney for Mexican asylum seekers in El Paso, Texas, June 22-23.

trac (Transactional Records Access Clearinghouse)

2012a "Immigration Court Backlog Tool. Pending Cases and Length of Wait in Immigration Courts," Syracuse, Transactional Records Access Clearinghouse, http: / / trac. syr.edu/phptools / immigration/ court_backlog/, accessed February 5, 2014.

2012b Judge Thomas C. Roepke, FY 2006-2011, El Paso Immigration Court, Syracuse, http: / / trac.syr.edu/immigration/ reports / judgereports / 00054ELP / index. html, accessed February 5, 2014.

2012c Judge William L. Abbott, FY 2005-2011, El Paso Immigration Court, Syracuse, http:/ / trac.syr.edu/immigration/ reports/judge2010/00051ELP/index.html, accessed February 5, 2014.

TYLER, I.

2010 "Designed to Fail: A Biopolitics of British Citizenship," Citizenship Studies, vol. 14 , no. 1 , pp. $61-74$.

United Nations High Commissioner for RefugeEs

2012 "Displacement. The New 21st Century Challenge," Geneva, United Nations, http: / / unhcr.org / globaltrend sjune2013 / UNHCR\% 20GLOBAL\%20 TRENDS\%202012_V05.pdf.

2011 “A Year of Crises. UnHCR Global Trends 2011," Geneva, United Nations, http: / / www.unhcr.org/4fd6f87f9.html.

2010 "Asylum Levels and Trends in Industrialized Countries, 2010, Statistical Overview of Asylum Applications Lodged in Europe and Selected Non-European Countries," Geneva, United Nations. 
2009 “Global Trends: Refugees, Asylum-seekers, Returnees, Internally Displaced and Stateless Persons," Geneva, United Nations, http:/ /www.unhcr.org/ 4c11f0be9.html.

2008 “Global Trends: Refugees, Asylum-seekers, Returnees, Internally Displaced and Stateless Persons," Geneva, United Nations, http:/ /www.unhcr.org/ 4a375c426.html.

2007 "Asylum Levels and Trends in Industrialized Countries, 2007, Statistical Overview of Asylum Applications Lodged in Europe and Selected Non-European Countries," Geneva, United Nations.

United States Court of Appeals for the Fifth Circuit

2011 Demiraj vs Holder, The United States Court of Appeals for the Fifth Circuit.

usdoj (United States Department of Justice)

2011 "Asylum Statistics by Nationality," The United States Department of Justice, http:/ / www.justice.gov / eoir/ efoia/ foiafreq.htm.

VACCOTTI, L.

$\mathrm{n} / \mathrm{d}$ "Biopolíticas de la inmigración y derechos humanos de los inmigrantes en Argentina," Buenos Aires, CONICET-Instituto de Investigaciones Gino Germani, Facultad de Ciencias Sociales, Universidad de Buenos Aires, http: / / www.iigg .fsoc.uba.ar/pobmigra/archivos/vaccotti_biopoliticas.pdf, accessed June 1, 2011.

YUING, T.

2011 "Migraciones y administración de la vida en el mundo," Psicoperspectivas. Individuo y sociedad, vol. 10, no. 1, pp. 6-20.

ZYLINSKA, J.

2004 "The Universal Acts. Judith Butler and the Biopolitics of Immigration," Cultural Studies, vol. 18 , no. 4, pp. 523-537. 